Dept of Pharmacology,

Animal Health Research Institute, Tanta Provincal lab.

\title{
COMPARATIVE PHARMACOKINETICS OF FLORFENICOL AFTER INTRAVENOUS, INTRAMUSCULAR AND SUBCUTANEOUS INJECTION IN SHEEP
}

(With 2 Tables and One Figure)

\author{
By \\ W.M.A. EL-SHEIKH; H.M. SHAHEEN* \\ and A. EL-GHONEIMY* \\ * Dept of Pharmacology, Faculty of Veterinary Medicine, \\ South Valley University, Qena. \\ (Received at 15/11/2008)
}

مقارنات فارماكوكينيتيكية على الفلورفينكول بعد حقته بالوريد والعضل وتحت الجلد في الأغنام

\section{وجيه مصطفي عبل السلام الثيخ ، حازم محمد شاهين ، أثرف الغتيسي}

تم حقن جر عة و احدة من عقار الفلورفينكول 20ملجم/كجم من وزن الحيو ان بالوريد أو

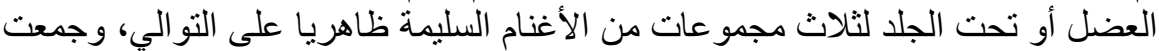
عينات من سيرم الدم لمدة 24ساعة لقياس مستوى العقار باستخدام جهاز الضغط العالي السائل السائل

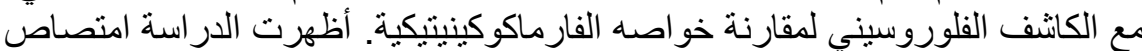

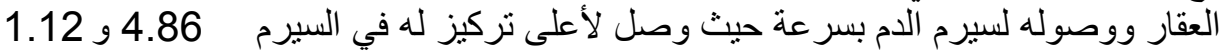

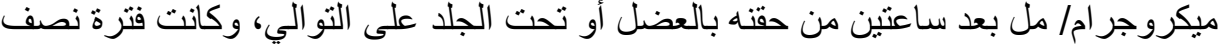

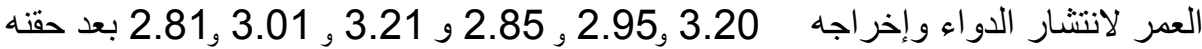

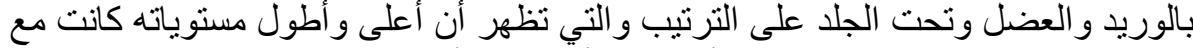

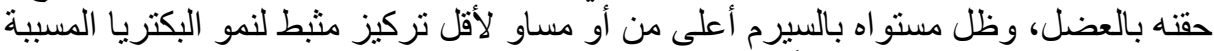

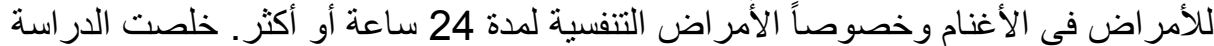

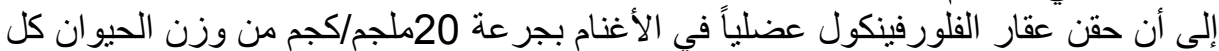
24 ساعة كافي لعلاج الأمر اض التي تسبيها الميكروبات الحساسة لهذا العقار.

\section{SUMMARY}

A single dose of florfenicol (20mg/kg b.w.) were injected either i.v., i.m. or s.c respectively for 3 groups of apparently healthy sheep (five animals of each) for comparing its pharmacokinetic properties. The drug concentrations in serum samples were measured for $24 \mathrm{~h}$ using HPLC 
with fluorescence detection. Results showed a rapid absorption for the drug reaching to maximum serum concentrations $(4.86$ and $1.12 \mu \mathrm{g} / \mathrm{ml})$ during $2 \mathrm{~h}$ after i.m. or s.c. injections while the distribution and elimination half-lives were 3.20, 2.95, 2.85 and 3.21, 3.01, 2.81 after i.v., i.m. and s.c injections respectively which clearly revealed the high and prolonged levels were with i.m. injection. The drug plasma levels were maintained more than or equal to MIC recorded for major pathogenic bacteria causing diseases in sheep (specially respiratory ones) for $24 \mathrm{~h}$ or more. The study concluded that, florfenicol is a good drug for treating sheep diseases caused by bacteria sensitive to it and one i m. dose $(20 \mathrm{mg} / \mathrm{kg}$. b.w.) every $24 \mathrm{~h}$ is enough.

Key words: Florfenicol, pharmacokinetics, sheep, HPLC

\section{INTRODUCTION}

Florfenicol is a novel broad-spectrum antibiotic; for animal use only, belong to the family of agents that include thiamphenicol and chloramphenicol, and have the same antibacterial mechanism and spectrum. It acts by inhibiting bacterial protein synthesis by binding to $50 \mathrm{~S}$ and $70 \mathrm{~S}$ subunits in the ribosomes (Cannon et al., 1990) and has potent activities against a broad spectrum of bacterial strains including most of Gram-negative and positive bacteria frequently occurring in animal herds (Neu and Fu, 1980; Suzuki, et al, 1989; Cannon et al, 1990; Ueda and Suenaga, 1995 and Barigazzi, et al, 1996). The structural modifications in the design of florfenicol (substitution of a fluorine atom for the hydroxyl group at C-3 site) prevent its acetylation by chloramphenicol acetyltransferase (CAT) present in resistant organisms so it has greater in vitro and in vivo activities at lower concentrations against many chloramphenicol-resistant or thiamphenicol-resistant strains involved with common infections in domestic animals (Neu and Fu, 1980; Syriopoulou et al., 1981; Graham et al., 1988; Sams, 1995 and Ueda and Suenaga, 1995). Furthermore it not contains the nitro group (present in chloramphenicol) so the aplastic anaemia is not associated with its administration (Yunis, 1988; Sams, 1995). Because of all these distinct advantages relating to safety and efficacy over chloramphenicol and thiamphenicol, florfenicol is believed to be an ideal replacement of these two drugs (Jianzhong, et al, 2004). So the objective of the study was comparing the pharmacokinetic parameters of florfenicol after a single intravenous (i.v.), intramuscular 
(i.m.) and subcutaneous (s.c.) injection in sheep for recommendation by more suitable method for its injection.

\section{MATERIALS and METHODS}

A-Drug: florfenicol (Nuflor ${ }^{\circledR} 300 \mathrm{mg} / \mathrm{ml}$ injectable solution ScheringPlough Animal Health Middle East Africa Operation). It is a structural analog of chloramphenicol and a fluorinated derivative of thiamphenicol (Bruce et al 1998). Florfenicol showing high in vitro potency against pathogenic bacteria mainly those associated with respiratory diseases in cattle and sheep as Pasteurella sp. and Haemophilus somnus (Neu and $\mathrm{Fu}, 1980$ and Syriopoulou et al., 1981) as well as enteric bacteria that are resistant to chloramphenicol and thiamphenicol (Atef et al., 2001).

B- Animals:- Fifteen 8-10 months old apparently healthy sheep (30 \pm $8.3 \mathrm{~kg}$ ) of mixed sex, fed on balanced rations (free from any drug or growth promoter) ad libitum with free access to water were randomly allocated into 3 groups (five animals of each) inside separate pens during the experiment. These animals were put under observation for 2 weeks before injection with a single dose of florfenicol $(20 \mathrm{mg} / \mathrm{kg} \mathrm{b.w.)} \mathrm{either}$ i.v., i.m. or s.c. for group 1, 2, and 3 respectively.

C- Sampling: Blood samples $(3-5 \mathrm{~mL})$ were taken from the contralateral vein of each sheep prior and at 5, 10, 15, 30, 40min, 1, 2, 4, 8, 12, 18 and $24 \mathrm{~h}$ after drug injection. The blood samples were allowed to clot at room temperature for $1 \mathrm{~h}$, and then the serum was decanted after centrifugation at $1300 \mathrm{~g}$ for $10 \mathrm{~min}$ and stored at $-20{ }^{\circ} \mathrm{C}$ until analysis. Drug concentrations in serum samples were determined by HPLC with fluorescence detection with quantitation limits of $0.05 \mu \mathrm{g} / \mathrm{ml}$ according methods described by Varma et al. (1986).

The HPLC system consisted of 1525 binary HPLC pump (Waters, Version Number Control Firmware 1.06. CPU Firmware1.3, USA), 717 plus autosampler (Waters, Version Number 3.1, USA), degasserin-Line2 Cham AF (Waters, Version Number 1.04, USA), 2475 multi $\lambda$ fluorescence detector (Waters, Version Number 1.00, USA ) and software Breeze (Waters Breeze ${ }^{\mathrm{TM}}$ HPLC system software).

D- Standard: florfenicol: from Dr. Ehrenstorfer GmbH D-86199 Augsburg Germany (Reference Standard) Cat. No. C 13665000 CAS 76639-94-6.

E- Analysis: Statistical were carried out according SAS (1987), and the kinetic parameters were calculated according to Baggot (1977). 


\section{RESULTES}

The maximum concentrations of florfenicol were reached after $2 \mathrm{~h}$ in each of i.m. and s.c. injections and the serum levels were still measured until $24 \mathrm{~h}$ after i.v.., i.m. and s.c. injections but the highest level was with i.m. one (Table1 and Fig. 1). While $t_{1 / 2 \alpha}$ and $t_{1 / 2 \beta}$ were $3.20,3.21,2.95,3.01$ and $2.85,2.81$ with i.v.., i.m. and s.c. injections respectively (Table 2 ).

Table 1: Serum concentrations $(\mu \mathrm{g} / \mathrm{ml})$ of florfenicol after a single i.v., i.m. and s.c. injection (20mg/kg b.w.) in healthy sheep.

\begin{tabular}{|c|c|c|c|}
\hline Time of sampling & $\begin{array}{c}\text { i.v. } \\
(\mathrm{n}=5) \\
\text { mean } \pm \text { SD }\end{array}$ & $\begin{array}{c}\text { i.m. } \\
(\mathrm{n}=5) \\
\text { mean } \pm \text { SD }\end{array}$ & $\begin{array}{c}\text { s.c. } \\
(\mathrm{n}=5) \\
\text { mean } \pm \text { SD }\end{array}$ \\
\hline $5 \mathrm{~min}$ & $35.61 \pm 4.53$ & $\mathrm{ND}$ & $\mathrm{ND}$ \\
\hline $10 \mathrm{~min}$ & $22.46 \pm 4.36$ & $1.13 \pm 0.52$ & $\mathrm{ND}$ \\
\hline $15 \mathrm{~min}$ & $20.28 \pm 5.01$ & $1.62 \pm 0.77$ & $0.86 \pm 0.77$ \\
\hline $30 \mathrm{~min}$ & $14.83 \pm 3.02$ & $3.13 \pm 1.85$ & $0.93 \pm 0.78$ \\
\hline $40 \mathrm{~min}$ & $14.06 \pm 5.29$ & $3.26 \pm 1.50$ & $0.96 \pm 0.68$ \\
\hline $1 \mathrm{~h}$ & $11.91 \pm 4.63$ & $3.94 \pm 1.76$ & $1.03 \pm 0.70$ \\
\hline $2 \mathrm{~h}$ & $7.34 \pm 4.51$ & $4.86 \pm 1.81$ & $1.12 \pm 0.57$ \\
\hline $4 \mathrm{~h}$ & $4.61 \pm 2.79$ & $4.21 \pm 1.56$ & $0.94 \pm 0.47$ \\
\hline $8 \mathrm{~h}$ & $1.64 \pm 0.96$ & $2.36 \pm 0.93$ & $0.74 \pm 0.33$ \\
\hline $12 \mathrm{~h}$ & $0.89 \pm 0.31$ & $1.61 \pm 0.57$ & $0.70 \pm 0.34$ \\
\hline $18 \mathrm{~h}$ & $0.40 \pm 0.24$ & $1.34 \pm 0.38$ & $0.61 \pm 0.31$ \\
\hline $24 \mathrm{~h}$ & $0.24 \pm 0.16$ & $1.19 \pm 0.25$ & $0.48 \pm 0.27$ \\
\hline
\end{tabular}

Table 2: Pharmacokinetic parameters of florfenicol after a single i.v., i.m. and s.c. injection ( $20 \mathrm{mg} / \mathrm{kg}$ b.w.) in healthy sheep.

\begin{tabular}{|c|c|c|c|c|}
\hline \multicolumn{2}{|c|}{ pharmacokinetic parameters } & \multirow{2}{*}{$\begin{array}{c}\text { i.v. } \\
(\mathrm{n}=5) \\
\text { mean } \pm \text { SD }\end{array}$} & \multirow{2}{*}{$\begin{array}{c}\begin{array}{c}\text { i.m. } \\
(\mathrm{n}=5)\end{array} \\
\text { mean } \pm \mathrm{SD} \\
4.86 \pm 0.21\end{array}$} & \multirow{2}{*}{$\begin{array}{c}\text { s.c. } \\
(\mathrm{n}=5) \\
\text { mean } \pm \text { SD } \\
1.12 \pm 0.09\end{array}$} \\
\hline $\mathrm{C}_{\max }$ & $\mu \mathrm{g} / \mathrm{ml}$ & & & \\
\hline $\mathrm{t}_{\max }$ & $\mathrm{h}$ & ------ & $2 \pm 0.05$ & $2 \pm 0.05$ \\
\hline AUC & $\mu \mathrm{g} / \mathrm{ml} . \mathrm{h}$ & $61.25 \pm 1.25$ & $50.51 \pm 1.51$ & $18.95 \pm 1.55$ \\
\hline $\mathrm{t}_{1 / 20}$ & $\mathrm{~h}$ & $3.20 \pm 0.15$ & $2.95 \pm 0.21$ & $2.85 \pm 0.11$ \\
\hline $\mathrm{T}_{1 / 2 \beta}$ & $\mathrm{h}$ & $3.21 \pm 0.28$ & $3.01 \pm 0.28$ & $2.81 \pm 0.11$ \\
\hline \multicolumn{3}{|c|}{$\mathrm{C}_{\max }=$ maximum concentration } & \multicolumn{2}{|c|}{$\mathrm{t}_{1 / 2 \alpha}=$ distribution half-life } \\
\hline \multicolumn{3}{|c|}{$\begin{array}{c}\mathrm{t}_{\max }=\text { time to maximum concentration } \\
\mathrm{AUC}=\text { area under the concentration time curve }\end{array}$} & \multicolumn{2}{|c|}{$\mathrm{t}_{1 / 2 \beta}=$ terminal elimination half-life } \\
\hline
\end{tabular}




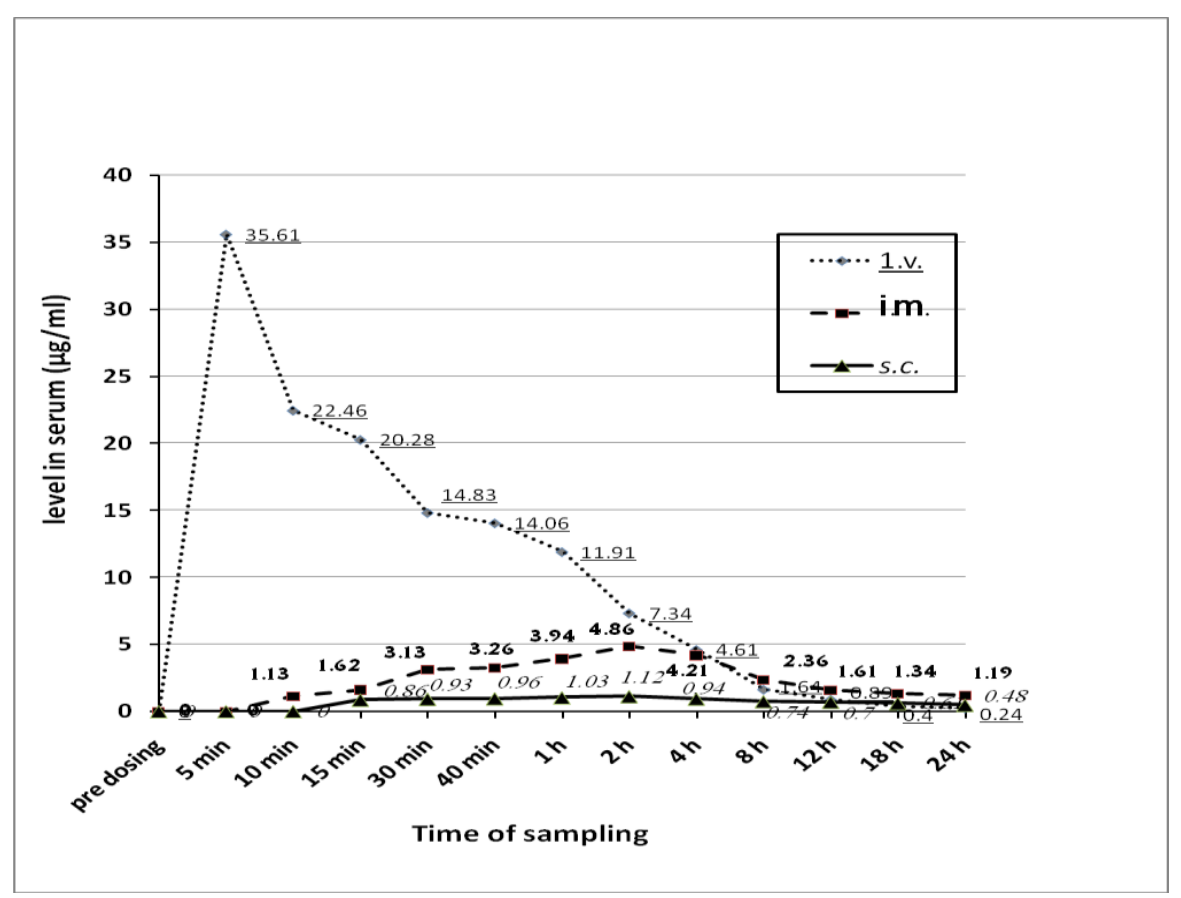

Fig. 1: Serum concentrations $(\mu \mathrm{g} / \mathrm{ml})$ of florfenicol after a single i.v., i.m. and s.c injection $(20 \mathrm{mg} / \mathrm{kg}$ b.w.) in healthy sheep

\section{DISCUSSION}

The structural modifications of florfenicol than its analog chloramphenicol (replacement of the hydroxyl group by a fluorine atom) postponed the in vivo metabolic glucuronidation and delaying its excretion that resulted a rapid distribution and a slow elimination phase with greater $\mathrm{AUC}_{0-\alpha}$, volume of distribution at steady state and elimination half-life values than those of chloramphenicol (Bretzlaff et al., 1987).

This study showed that the florfenicol was rapidly absorbed and reached to serum with high levels (specially with i.m. injection) where $\mathrm{C}_{\max }$ were 4.86 and $1.12 \mu \mathrm{g} / \mathrm{ml}$ after $\mathrm{t}_{\max } 2$ and $2 \mathrm{~h}$ with i.m. and s.c. injection respectively. These results were in agreement with the findings of Jianzhong et al. (2004) and Lane et al. (2004) after injection of sheep with a single dose of florfenicol $20 \mathrm{mg} / \mathrm{kg}$ b.w. i.m. in the $1^{\text {st }}$ study and $40 \mathrm{mg} / \mathrm{kg}$ b.w. s.c. in the $2^{\text {nd }}$ study and recorded $\mathrm{C}_{\max } 4.13$ and $2.64 \mu \mathrm{g} / \mathrm{ml}$ after $\mathrm{t}_{\max } 1.45$ and $2 \mathrm{~h}$ respectively. In contrast we found Atef et al. (2000) and Ali et al. (2003) recorded more less $C_{\max }(0.859$ and $1.04 \mu \mathrm{g} / \mathrm{ml})$ 
when inject $20 \mathrm{mg} / \mathrm{kg}$ b.w. of florfenicol i.m. in goat and sheep respectively. These differences in results may be related; at least partially, to difference in the analytical methods used in these studies where the microbiological assay (used in last 2 studies) measures only the unbound and the microbiological active compound, however the HPLC (used in present and first 2 studies) measures the total concentration of florfenicol (Atef et al. (2001).

On the other hand in this study The AUC values were 61.25, 50.51 and $18.95 \mu \mathrm{g} / \mathrm{ml}$.h after i.v., i.m. and s.c. injections respectively which although its partial different than $76.31,67.95$ and $28.3 \mathrm{gh} / \mathrm{mL}$ recorded by Jianzhong et al. (2004) and Lane et al. (2004) but all these results were much larger than those previously reported for both nonlactating goats (Atef et al., 2001) and lactating goats (Lavy et al., 1991), that revealed rapid distribution of florfenicol in sheep than in goats (Jianzhong et al., 2004). While $\mathrm{t}_{1 / 2 \alpha}$ was $3.20,2.95$ and $2.85 \mathrm{~h}$ after i.v., i.m. and s.c. administrations of florfenicol which more higher than $1.51 \mathrm{~h}$ reported by Jianzhong et al. (2004) after i.v. injection of florfenicol whose commented that this result indicated a rapid distribution in shallow peripheral compartment and a slow distribution in deep peripheral compartment.

Furthermore this study showed that florfenicol as characterized by rapid absorption also characterized by slow elimination phase where the terminal elimination half-lives $\left(\mathrm{t}_{1 / 2 \beta}\right)$ were $3.21,3.01$ and $2.81 \mathrm{~h}$ after i.v., i.m and s.c. injection respectively were partially near to those reported by Ali et al. (2003) 1.3 and $2.28 \mathrm{~h}$ than those reported by Jianzhong et al. (2004) 18.83 and 10.34h after i.v. and i.m. injection of $20 \mathrm{mg}$ in sheep respectively, and nearly similar to $2.35,2.61 \mathrm{~h}$ reported in goats by Lavy et al., 1991 and Atef et al., 2001 respectively.

It must be mentioned that this study clearly illustrated that although the dose is same with i.v., i.m. and s.c. injections we found main differences to side of i.m. than i.v. and s.c. routs (e.g.) at 18 and $24 \mathrm{~h}$ after i.v and i.m. injections, the drug levels with i.m. were 3.35 and 5 times respectively higher than its levels after i.v. ones (1.34 and1.19 with i.m.; and 0.40 and $0.24 \mu \mathrm{g} / \mathrm{ml}$ with i.v. one). Also at the same time ( $2 \mathrm{~h}$ after injection) the $\mathrm{C}_{\max }$ with i.m. was more high (nearly 4 time) than s.c. rout (4.86 and $1.12 \mu \mathrm{g} / \mathrm{ml}$ respectively). Furthermore we observe the high and prolonged levels of main parameters as AUC, $t_{1 / 2 \alpha}$ and $t_{1 / 2 \beta}$ (specially AUC) with i.m. than s.c. injection that were 50.51, 2.95 and 3.01 with i.m. injection while were $18.95,2.85$ and 2.81 after s.c. injection respectively. These differences may be due to the organic long- 
acting formulation of florfenicol that cause a delay in its absorption from the injection site in the muscle (Liu et al., 2003) and not resulted from adverse reaction at the site of i.m. injection (Jianzhong et al., 2004) where they not observe any adverse reaction at the site of i.m. administration could alter the drug absorption although they added the variability in absorption from the i.m. injection site itself can occur due to the differences in regional blood flow for different muscle tissues.

Because the minimum inhibitory concentrations (MICs) of florfenicol for bacteria isolated from sheep have not yet been available for comparing with serum levels, we can guiding by that recorded for isolates from other species, as that recorded for 90 strains of Actinobacillus pleuropneumoniae isolated from porcine pneumonic lungs in Japan during 1989 to 1993 by Ueda and Suenaga, (1995) and ranged from 0.2 to $1.56 \mu \mathrm{g} / \mathrm{ml}$ with a peak at $0.39 \mu \mathrm{g} / \mathrm{ml}$ while ranged from 0.2 to $0.39 \mu \mathrm{g} / \mathrm{ml}$ for seven thiamphenicol-resistant strains. Also Barigazzi, et al. (1996) recorded MIC average $0.25 \mu \mathrm{g} / \mathrm{ml}$ for 108 A. pleuropneumoniae strains isolated from pig lungs in Italy, Bruce et al. (1998) recorded MIC rang $(0.125-1.0 \mu \mathrm{g} / \mathrm{ml})$ for pathogenic bacteria (Pasteurella and Haemophilus $s p$ ) isolated form respiratory infection in calves, and Priebe and Schwarz (2003) mentioned that MIC of florfenicol was $\leq 2 \mu \mathrm{g} / \mathrm{ml}$ against 756 bacterial isolates form respiratory tract infection in cattle and swine. Recently, Shin et al. (2005) found that $\mathrm{MIC}_{90}$ of florfenicol was $\leq 1 \mu \mathrm{g} / \mathrm{ml}$ against 243 bacterial agents $(A$. pleuropneumoniae, P. multocida, Mannheimia haemolytica and Bordetella bronchiseptica) isolated in Korea from cattle and pigs with respiratory diseases.

In keeping with this line Bretzlaff et al. (1987); Inglis and Richards, (1991) and Ueda and Suenaga, (1995) concluded that florfenicol showed high efficacy against most bacteria isolated from fish, swine, calves and cows, Shin et al. (2005) said that florfenicol is therapeutically valuable in the treatment of primary or complicating bacterial pathogens causing of the bovine and swine respiratory tract diseases, and Berge et al. (2006) mentioned that the most common isolates from respiratory tract diseases of sheep and goats in USA (28 isolates of $P$. multocida and 39 of $M$. haemolytica) were highly susceptible in vitro to florfenicol and its treatment with florfenicol is not complicated by antimicrobial resistance.

Based on these recorded MIC for bacterial isolates commonly associated with animal infections (specially respiratory diseases) and these authors conclusions, can said that the serum levels of florfenicol in 
the present study were still more than these determined MIC for $24 \mathrm{~h}$ or more specially with i.m. injection, subsequently florfenicol when given i.m. only one time a day $(20 \mathrm{mg} / \mathrm{kg}$ b.w.) can maintain the therapeutic concentrations required for controlling the bacterial diseases in sheep caused by microorganisms susceptible in vitro to this drug. Nearly similar conclusion previously reported by Jianzhong et al. (2004) but with dose $30 \mathrm{mg} / \mathrm{kg}$ b.w every $24 \mathrm{~h}$ and they commented that this difference in doses (20 and 30mg) with i.m. injection have no significant values in main parameters as residence time $\mathrm{t}_{1 / 2 \alpha}, \mathrm{t}_{1 / 2 \beta}, \mathrm{t}_{\max }$ and systemic bioavailability where these values were $0.27 \mathrm{~h}, 0.25 \mathrm{~h} ; 10.34 \mathrm{~h}, 9.57 \mathrm{~h}$; $1.45 \mathrm{~h}, 1.34 \mathrm{~h}$ and $89.04,85.52 \%$ after i.m. injection of florfenicol in sheep at a dose 20 and $30 \mathrm{mg} / \mathrm{kg}$ b.w. respectively.

Finally can concluded that, florfenicol is a good drug for treating sheep diseases (specially respiratory ones) and its level in serum persist more than or equal to MIC recorded for the main isolated bacterial pathogens for at least $24 \mathrm{~h}$ and i.m. injection is the better method for administration so one i.m. dose (20mg/kg. b.w.) daily is enough.

\section{REFERENCES}

Ali, B.H.; Al-Qarawi, A.A. and Hashaad, M. (2003): Comparative plasma pharmacokinetics and tolerance of florfenicol following intramuscular and intravenous administration to camels, sheep and goats. Vet. Res. Commun 2003; 27(6): 475-83.

Atef, M.; El-Gendi, A.Y.; Aziza, M.M. and Abd El-Aty, A.M. (2000): Pharmacokinetic properties of florfenicol in Egyptian goats. Dtsch Tierarztl Wochenschr 107(4): 147-150.

Atef, M.; El-gendi, Y.I.; Amer, A.M.M. and Abd El-Aty, A.M. (2001): Disposition kinetics of florfenicol in goats by using two analytical methods. J. Vet. Med. A Physiol. Pathol. Clin. Med., 48, 129-136.

Baggot, J.D. (1977): Principles of drug disposition in domestic animals: The basis of Veterinary Clinical Pharmacology. WB Saunders, Philadelphia 144-189.

Barigazzi, G.; Candotti, P. and Foni, E. (1996): In vitro susceptibility of 108 isolated Actinobacillus pleuropnemoniae strains to 17 antimicrobial agents from pig lungs in Italy in 1994-1995. In Proceeding of the $14^{\text {th }}$ International Pig Veterinary Society Congress, Bologna, Italy, p 207. 
Berge, A.C.; Sischo, W.M. and Craigmill, A.L. (2006): Antimicrobial susceptibility patterns of respiratory tract pathogens from sheep and goats. J. Am. Vet. Med. Assoc. 229(8): 1279-1281.

Bretzlaff, K.N.; Neff-Davis, C.A.; Ott, R.S.; Koritz, G.D.; Gustafsson, B.K. and Davis, L.E. (1987): Florfenicol in non-lactating dairy cows: pharmacokinetics, binding to plasma proteins and effects on phagocytosis by blood neutrophils. J. Vet. Pharmacol. Therap. 10, 233-240.

Bruce, R.; Hoar; Murray, D.; Jelinski; Cari, S.; Ribble; Eugene, D.; Janzen; John C. and Johnson (1998): A comparison of the clinical field efficacy and safety of florfenicol and tilmicosin for the treatment of undifferentiated bovine respiratory disease of cattle in western Canada. Can. Vet. J. (39): 161- 166.

Cannon, M.; Harford, S. and Davies, J. (1990): A comparative study on the inhibitory actions of chloramphenicol, thiamphenicol and some fluorinated derivatives. J. Antimicrob. Chemother. 26: 307-317.

Graham, R.; Palmer, D.; Pratt, B.C. and Hart, C.A. (1988): In vitro activity of florfenicol. Euro. J. Clin. Microbiol. and Infect. Dis., 7, 691-694.

Inglis, V. and Richards, R.H. (1991): The in vitro susceptibility of Aeromonas salmonicida and other fish-pathogenic bacteria to 29 antimicrobial agents. J. Fish Dis. 14, 641-650.

Jianzhong, S.; Xiubo, L.; Haiyang, J. and Walter, H.H. (2004): Bioavailability and pharmacokinetics of florfenicol in healthy sheep. J. Vet. Pharmacol. Therap. 27, 163-168.

Lane, V.; wetzlich, S.; Clifford, A.; Taylor, I. and Craigmill, A.L. (2004): Intravenous and subcutaneous pharmacokinetics of florfenicol in sheep. J. Vet. Pharmacol. Therap. 27, 191-196.

Lavy, E.; Ziv, G.; Soback, S.; Glickman, A. and Winkler, M. (1991): Clinical pharmacology of florfenicol in lactating goats. Acta Vet. Scand. (Sup):, 87, 133-136.

Liu, J.; Fung, K.F.; Chen, Z.; Zeng, Z. and Zhang, J. (2003): Pharmacokinetics of florfenicol in healthy pigs and in pigs experimentally infected with Actinobacillus pleuropneumoniae. Antimicrob Agents Chemother, 47(2): 820-823.

$\mathrm{Neu}, \mathrm{H} . \mathrm{C}$. and Fu, K.P. (1980): In vitro activities of chloramphenicol and thiamphenicol analogs. Antimicrob. Agents and Chemother. 18, 311-316. 
Priebe, S. and Schwarz, S. (2003): In vitro activities of florfenicol against bovine and porcine respiratory tract pathogens. Antimicrob. Agents and Chemother. 47(8): 2703-2705.

Sams, R.A. (1995): Chemistry and metabolism of a novel-broadspectrum antibiotic. Tieraerztliche Umschau, 50, 703-707.

Shin, S.J.; Kang, S.G.; Nabin, R.; Kang, M.L. and Yoo, H.S. (2005): Evaluation of the antimicrobial activity of florfenicol against bacteria isolated from bovine and porcine respiratory disease. Vet. Microbiology, 106(1-2): 73-77.

Statistical Analysis System, (1987): SAS User's Guide: Statistical Methods. SAS Institute, Inc., Cary, North Carolina.

Suzuki, S.; Ohmae, K. and Ohishi, K. (1989): Antimicrobial susceptibility of Actinobacillus (Haemophilus) pleuropneumoniae isolated from pig with pleuropneumonia. Jpn. J. Vet. Sci. 51: 450-452.

Syriopoulou, V.P.; Harding, A.L.; Goldmann, D.A. and Smith, A.L. (1981): In vitro antibacterial activity of florfenicol analogs of chloramphenicol and thiamphenicol. Antimicrob. Agents and Chemother. 19: 294-297.

Ueda, Y. and Suenaga, I. (1995): In vitro antimicrobial activity of florfenicol against Actinobacillus pleuropneumoniae. J. Vet. Med. Sci. 57: 363-364.

Varma, K.J.; Adams, P.E.; Powers, T.E.; Powers, J.D. and Lamendola, J.F. (1986): Pharmacokinetics of florfenicol in veal calves. J. Vet. Pharmacol Ther, 9(4): 412-425.

Yunis, A.A. (1988): Chloramphenicol: relation of structure to activity and toxicity. Annual Review of Pharmacol. Toxicol., 28, 83-100. 
Assiut Vet. Med. J. Vol. 55 No. 120 January 2009 